\title{
Gender Based on ESL Writing Mastery and Writing Perception of Non-Native English Community
}

\author{
Putri Maharani ${ }^{*}$ and Farah Fadilah ${ }^{2}$ \\ ${ }^{1}$ Department of English Language Education, Universitas Veteran Bangun Nusantara Sukoharjo, Indonesia \\ and ${ }^{2}$ Department of English Language and Literature Studies, Universitas Hasanuddin, Makassar, Indonesia \\ *mahaputri19@gmail.com
}

\begin{abstract}
Writing is considered an essential skill for academic purpose. This research aims: 1. to explore the difference of students' English writing mastery based on gender, 2) to explore the difference English writing perceptions based on gender. The study deploys a mixed method through a convergent parallel design that engages both quantitative and qualitative phases consecutively. It involves 26 first-year English Education Department students at Universitas Veteran Bangun Nusantara Sukoharjo, Indonesia in the production of explanatory paragraph writing and questionnaire survey. The findings of the quantitative phase results in tcalc $\leq \mathrm{ttab}$ $(0.685 \leq 2.080)$ on English writing mastery and tcalc $\leq \operatorname{ttab}(1.114 \leq 2.306)$ on English writing perception among female and male students, indicating there is no significant difference on both variables. The finding of the qualitative phase reveals only a small gap of both variables between the two gender. The study implies an initiative in investigating the contributing socio-innate factors to the students' English language capacity. Keywords - ESL writing mastery, ESL writing perception, gender.
\end{abstract}

Key words: ESL writing mastery, ESL writing perception, gender.

\section{Introduction}

Gender is a factor that distinguishes the variations of human language. According to Lakoff, males and females have distinctive intensities in utilizing certain language features, such as hedges, intensifiers, and tag questions [1]. A number of studies revealed that females tend to be closer to Standard English compared to males [2] [3] despite the existence of gender bias [4]. With regards to the aforementioned notion, the researchers suspected several factors that may differentiate male and female language features in English writing skills.

When dealing with any types of language skills, another component that may affect the learners' capability is their perception that leads to the quality of motivation [4]. This study reveals whether gender relates to English writing perception.

This research is an attempt to generate an understanding on the relation between gender, English writing mastery, and English writing perception. Gender plays a central variable that is suspected to be the contributing factor that defines the students writing skill and writing perception. The finding is expected to provide a reference for education sector in considering more proper English language curriculum that fits based on respective individual innate characteristics. 


\section{Theoretical Reviews}

\section{Gender And Language}

Gender is different from sex. The term refers to the social idea and practice that makes someone to be either male or female, while sex is a biological determination whether a person is masculine or feminine [6] [7] [8] [9]. As a common phenomenon that separates the system of being male and female, gender also represents the differences of language styles between the two groups, for instances, the utilization of hedges (e.g., umm..., you know..., sort of...), tag questions (e.g. 'We will come into the class, won't we?'), empty adjectives (e. g. marvelous, gorgeous, nice), precise color terms (e.g. tosca, fanta, peach), intensifiers (e.g. just, so), hypercorrect grammar, super-polite forms, emphatic stress (e.g. 'It was a very brilliant performance!'), and swearings (e.g. oh fudge) [1]. The different intensity of language feature utilization between males and females leads to the idea of "gender marking" [10]. As an impact, the difference also signifies the variations of how males and females should speak in order to be distinguished by the society [11]. Gender also represents the method of how a language is presented by a certain speech community [12]. Men tend to use interaction as a means of gaining and exchanging information, while women utilize it as a method to connect to others [13].

A number of studies reveal the differences of grammatical structure used by males and females. The most common point of view mentions that females tend to use minimum swearings, perceived more polite than men [14], in addition to being closer to standard English [2] [3]. While males intensively use interruptions and sentence-initial conjunction, females rely on questions, justifiers, intensive adverbs, personal pronouns, and word-initial adverbs [15]. As an implication, female users of English consider structure and politeness in communication, while males tend to be directive and brief.

\section{English Writing Skill}

In writing activity, English learners are expected to meet the demand of language skill, in which they have to intertwine cognitive aspects with the certain genre. They should understand three methods in assuring their writing quality, including text-oriented, writer-oriented, and reader-oriented [16].

Writing across curricula enables learners to express their ideas into written forms, in which they feel free to use progressive format, unique grammatical features, and certain display. A substantial shift in English writing toward the implementation of the process approach is an alternative for the traditional approach [17], providing learners with the variety of genres [16] [18] [19].

Placing the learners in the situation and atmosphere where they are interested in producing an authentic writing can facilitate them to meet their academic demands, especially when dealing with well-organized piece of writing [5]. As writing should be boosted with the "think-aloud" protocol, students may need a significant amount of time in completing their writing tasks [20] [21].

\section{English Writing Perception}

The relation between gender and second language acquisition defines the level of English skills between males and females [22]. Additionally, students' perceptions may also contribute to the level of encouragement in progressing their academic performance. Students, especially learners of English as a second language tend to make grammatical errors, as they tend to put the urgency of English for verbal communication [23]. Making the students aware of their learning needs in improving English writing skill can grow their perception about English as a second language, as an attempt to improve their writing capacity [5].

\section{Relevant Studies}

Differences in language style used by males and females have appeared common, leading to the belief that gender puts a gap in language [12]. However, a certain study mentions that females use an equal intensity of hedges [4] and registers [24] as males do, resulting in a conclusion that males and females tend averagely use the same intensity of English linguistic features. It is a substantive attempt to find out whether males and females signify difference in language styles, especially through their writings. Writing skill is considered as the most complex task among the four language skills that involve not only cognitive aspects but also constructive knowledge. The differences of linguistic aspects between males and females may be generated in this stage through this study, allowing a further analysis which group tends to be closer to standard English and fulfills adequate skill in writing as well as another group that should be improved.

Language skill capacity depends not only on gender but also the learners' perception about a certain language they use [5]. If gender is suspected to affect the students' writing skill, this study also considers that gender also contributes to how males and females view English as their practical language. One's perception may shape a vivid 
point of view that leads to an intrinsic motivation in dealing with English language, especially writing skill. Therefore, this study is directed to reveal how gender may contribute to the level of English writing mastery and how gender may affect the students' perception in dealing with English writing activities.

\section{Methodology}

\section{Research Design}

Referring to the pragmatism, this research is directed to emphasize more on the result of actions, situations, and consequences than antecedent conditions [25] by focusing on problems that require multiple approaches [26]. It adopts a parallel design by engaging the closed-ended quantitative and at the same time opened-ended qualitative approaches through a mix method. By comparing the results generated by the quantitative approach and qualitative approach, a comparison is drawn to provide either confirmation or disconfirmation to Lakoff's theory regarding gender and language. A further analysis will follow through the revelation if gender may contribute to the variation of English writing perception among the participants.

\section{Participants}

This research involves the first-year students of English Education Department at Universitas Veteran Bangun Nusantara Sukoharjo during the 2016/2017 academic year, consisting of 26 students. Among the students, 17 are females, while the other nine are males. All of the students were involved during the quantitative phase through a total sampling. Meanwhile, only five representatives were chosen to proceed to the qualitative phase through a purposive selection based on their English writing scores at the previous phase.

\section{Data Collection}

During the quantitative phase, the participants are given a writing task to produce an explanatory paragraph themed emancipation, which is the active subject that they received from their lecturer during the organization of this study. From the task, a scoring rubric inspired by Mertler is utilized as a quantitative instrument to define each individual and each gender's capacity in English Writing based on a 1-to-4 scale [27]. The scoring rubric highlights the students' capacity in elaborating their writings and rates of grammatical accuracy based on Azzar's 14 grammatical error types, including singular-plural, word form, word choice, verb tense, addition, omission, word order, incomplete sentence, spelling, capitalization, article, punctuation, unclear meaning, and run-on sentence [28]. This first instrument facilitates the data collection regarding the students' English writing mastery based on respective genders. Additionally, a 5-scale Likert questionnaire highlighting the students' perception and tendency about English writing is utilized as the second instrument. The Likert questionnaire quests the students' view on their own English writing capacity and their favorite English writing class activities. The instruments are affirmed through a reliability test using Cronbach Alpha with a requirement rcalc $>\mathrm{rtab}$ at $95 \%$ confidence level with a minimum value $=0.60[294]$.

\section{Data Analysis}

Using a side-by-side comparison, this research consecutively considers the findings of both phases to draw a confirmation or disconfirmation to the previous idea proposed by Lakoff regarding gender and language. Following the data collection, an analysis follows with several steps. First, the results of the students' explanatory paragraph writings are assessed using Mertler's scoring rubric, in which a perfect score reaches 16 . This is directed to generate a quantitative finding regarding the differences of English writing quality between males and females. Second, a 5-scale Likert questionnaire aims to explore the students' perceptions regarding their capability in producing English writing. The questionnaire consists of variables. As for the quantitative analysis, the independent samples $\mathrm{t}$-test is deployed to reveal the significance of gender to English writing skill and English writing perception by the requirement rcalc $\geq$ rtab at $95 \%$ confidence level.

Third, following the quantitative scoring, a deeper analysis on the grammatical accuracy is performed. Fourth, the students' answers on the Likert questionnaire are also utilized to generate an explanation on how gender may affect the quality of English writing mastery and English writing perception. At this qualitative phase, an analysis is performed through documents and records. To generate an extensive understanding, a formal interview with the lecturer is also included. 
Table 1. Analytic Scoring Rubric Established by Mertler (2001: 2) for The Scoring of Explanation Paragraph Writing

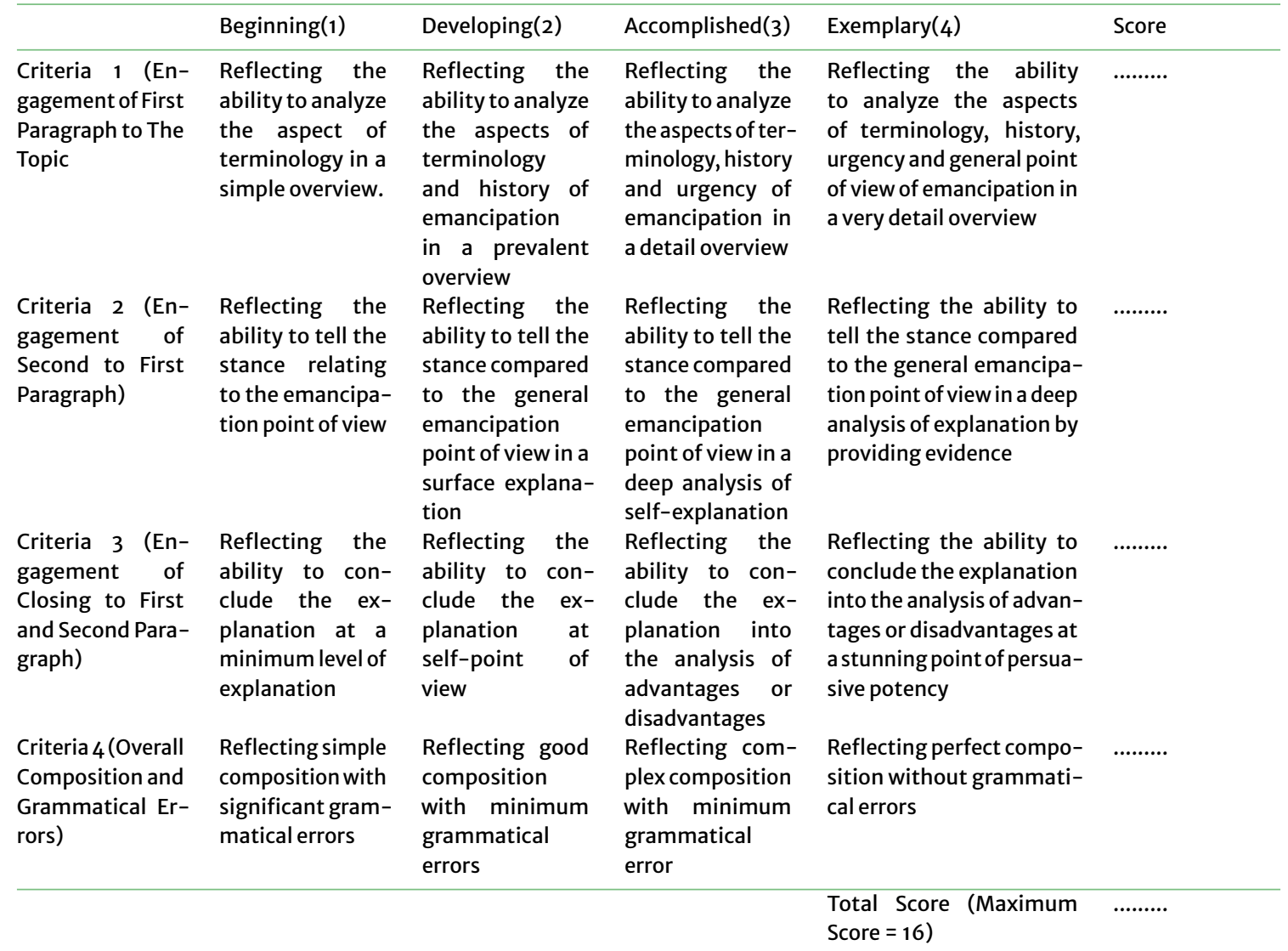

\section{Findings and Discussion}

\section{Gender toward English Writing Skill}

\section{Quantitative Phase}

The scoring shows that females gained a higher average score (9.94) compared to males (8.71), indicating that females possess a higher competency in English writing compared to males. The independent samples t-test generates tcalc $\leq \mathrm{ttab}(0.685 \leq 2.080)$, marking no differences between females and males in writing mastery.

\section{Qualitative Phase}

A total of five female and five male students are drawn based on their top scores to proceed to the qualitative phase through a purposive sampling. Regarding the first aspect of the scoring rubric, females and males tend to be able to reflect the ability to analyze the aspects of terminology, history, urgency, and general point of view of emancipation in a very detail overview. However, at the second aspect, female students show one level higher competence than male students. At the third aspect, emales also show the ability to conclude the explanation into the analysis of advantages or disadvantages with a persuasive tone, while males do not indicate this performance. As an early deduction, females are more meticulous than males. At the fourth aspect, females are also one level higher ability than males in terms of grammatical accuracy. Female students make less mistakes in singular-plural, word choice, verb tense, addition, word order, spelling, capitalization, punctuation, and clarity of meaning compared to males. In contrast, males are more proficient in avoiding mistakes regarding omission and incomplete sentences. Besides, both genders do not mistake in word form and run-on sentence. This finding indicates that female students have more minimum patterns of grammatical errors compared to male students.

\section{Gender toward English Writing Perception}

\section{Quantitative Phase}

The analysis 5-scale Likert questionnaire reveals an average value that females have a stronger perception (16.38) regarding their English writing quality compared to males (14.857). However, the result of t-test shows tcalc $\leq$ ttab $(1.114 \leq 2.306)$, indicating no difference in perceptions between males and females. 
Table 2. The Detail of English Understanding of Each Gender

\begin{tabular}{ll}
\hline Level of Understanding & Females \\
\hline $\begin{array}{l}\text { Engagement of First Para- } \\
\text { graph to The Topic }\end{array}$ & $\begin{array}{l}\text { Five among five females reflect the } \\
\text { ability to analyze the aspects of } \\
\text { terminology, history, urgency and } \\
\text { general point of view of emancipa- } \\
\text { tion in a very detail overview. }\end{array}$ \\
Engagement of Second to & $\begin{array}{l}\text { Four out of five females reflect the } \\
\text { ability to tell the stance compared } \\
\text { to the general emancipation point } \\
\text { of view in a deep analysis of expla- } \\
\text { nation by providing evidence. } \\
\text { One out of five females reflect the } \\
\text { ability to tell the stance compared } \\
\text { to the general emancipation point } \\
\text { of view in a deep analysis of self- } \\
\text { explanation }\end{array}$ \\
\end{tabular}

Engagement of Third to Fourth Paragraph

Overall Composition and Grammatical Errors
Three out of five females reflect the ability to conclude the explanation into the analysis of advantages or disadvantages at a stunning point of persuasive potency.

Two out of five females reflect the ability to conclude the explanation into the analysis of advantages or disadvantages

Four out of five females reflect complex composition with minimum grammatical errors.

One out of five female students reflects simple composition with significant grammatical errors.
Males

Three out of five females reflect the ability to analyze the aspects of terminology, history, urgency and general point of view of emancipation in a very detail overview.

One out of five males reflects the ability to analyze the aspects of terminology, history, urgency and general point of view of emancipation in a very detail overview

One out of five males reflect the ability to analyze the aspect of terminology in a simple overview.

Three out of five males reflect the ability to tell the stance compared to the general emancipation point of view in a deep analysis of selfexplanation.

One out of five males reflect the ability to tell the stance compared to the general emancipation point of view in a deep analysis of explanation by providing evidence.

One out of five males reflect the ability to tell the stance relating to the emancipation point of view.

Three out of five males reflect the ability to conclude the explanation into the analysis of advantages or disadvantages.

Two out of five males reflect the ability either to conclude the explanation into the analysis of advantages or disadvantages at a stunning point of persuasive potency or conclude the explanation into the analysis of advantages or disadvantages.

Three out of five males reflect simple composition with significant grammatical errors.

One out of five males reflects complex composition with minimum grammatical errors

One out of five males reflects good composition with minimum grammatical errors.

\section{Qualitative Phase}

Female and male students tend to agree of having perception that they do not surrender easily in doing English writing tasks. They state that they need visual supports to inspire them in defining appropriate themes for their tasks. A peer-review activity is also highlighted as an important means to boost their performance. The only difference between the two genders in terms of their English writing perception is the initiative of giving active feedbacks, in which females tend to be more enthusiastic while males tend to be neutral

As an extension, a formal interview with a faculty member was initiated, revealing that there is no significant difference on English writing skill among female and male students on daily basis. They tend to have average score in doing English writing tasks. Several factors, such as social-economic background, innate ability, motivation, and environment are believed to contribute more to the quality of English writing mastery compared to the traditional view on gender. Regarding the writing perception, the students share common behavior, preferences, and excitement in following English writing class from the first up to second semester, in which neither female nor male students show dominance.

The faculty member advised that this research should be continued gradually by also involving the upper term students and putting more highlights on the variations of learning styles, instruments, and learning environments.

At glance, the quantitative and qualitative phases respectively show different deduction. This result commonly occurs in a mixed-method design. The quantitative phase does not admit a significant difference between the two genders regarding English writing mastery, yet the qualitative phase confirms that female students show a better level of understanding than male students, yet the difference is only at the quality of paragraph details. This single difference can not be used to justify that there is a gap in English language mastery between the two genders and merely approve the previous theory proposed by Lakoff. The quantitative phase only shows a small deviation of 
Table 3. The Detail of ESL Writing Perception of Each Gender

\begin{tabular}{|c|c|c|}
\hline Statement & Females & Males \\
\hline \multirow[t]{3}{*}{$\begin{array}{l}\text { I do not surrender easily in } \\
\text { doing English writing tasks. }\end{array}$} & $\begin{array}{l}\text { Five out of five females agree to the state- } \\
\text { ment }\end{array}$ & Three out of five males strongly agree to the statement. \\
\hline & & One out of five males agree to the statement. \\
\hline & & One out of five males disagree to the statement \\
\hline \multirow{3}{*}{$\begin{array}{l}\text { I want there is a visual sup- } \\
\text { port to define what themes } \\
\text { I should choose for my En- } \\
\text { glish writing tasks. }\end{array}$} & $\begin{array}{l}\text { Three out of five females strongly agree to } \\
\text { the statement }\end{array}$ & Three out of five males agree to the statement. \\
\hline & $\begin{array}{l}\text { Two out of five females agree to the state- } \\
\text { ment }\end{array}$ & One out of five males strongly agree to the statement \\
\hline & & $\begin{array}{l}\text { One out of five males neither agree nor disagree to the state- } \\
\text { ment }\end{array}$ \\
\hline \multirow{4}{*}{$\begin{array}{l}\text { I want there is an active } \\
\text { feedback about my En- } \\
\text { glish writing tasks }\end{array}$} & $\begin{array}{l}\text { Two out of five females strongly agree to the } \\
\text { statement. }\end{array}$ & Two out of five males agree to the statement. \\
\hline & $\begin{array}{l}\text { Two out of five females neither agree nor dis- } \\
\text { agree to the statement. }\end{array}$ & One out of five males strongly agree to the statement \\
\hline & $\begin{array}{l}\text { One out of five females agree to the state- } \\
\text { ment. }\end{array}$ & $\begin{array}{l}\text { One out of five males neither agree nor disagree to the state- } \\
\text { ment. }\end{array}$ \\
\hline & & One out of five males disagree to the statement \\
\hline \multirow[t]{4}{*}{$\begin{array}{l}\text { Ineed a peer-review in En- } \\
\text { glish writing class }\end{array}$} & $\begin{array}{l}\text { Three out of five females agree to the state- } \\
\text { ment. }\end{array}$ & Two out of five males agree to the statement \\
\hline & $\begin{array}{l}\text { Two out of five females strongly agree to the } \\
\text { statement. }\end{array}$ & One out of five males strongly agree to the statement. \\
\hline & & $\begin{array}{l}\text { One out of five males neither agree nor disagree to the state- } \\
\text { ment. }\end{array}$ \\
\hline & & One out of five males disagree to the statement \\
\hline
\end{tabular}

average score between the two genders, resulting in a deduction that the qualitative phase highlights no significant difference of English writing mastery.

The findings have countered the previous notions [1] [2] [3] stating that females communicate closer to Standard English than males. In contrast, this research, which is directed to non-native English community finds insignificant difference at the variable of English writing mastery, thus automatically disconfirms the theories. It also reveals commonly similar perception of respective genders regarding their capability in English writing.

Female and male students involved in this research record common backgrounds that may affect their English writings, including social-economic backgrounds, innate ability, motivation, and environment. Therefore, they perform a similar learning mode. As the students are still in the first year, they require an adaptation to English, as part of the language they should use in communication. Therefore, their progress has not been significant.

\section{Conclusion}

The findings of the quantitative and qualitative phases show insignificant difference between gender and both English writing mastery and English writing perception. This research is specified to investigate the interaction between the three variables among non-native English community, and as a result, it countered the previous prominent notion proposed by Lakoff. As an implication, this research suggests an equal learning opportunity for respective genders. Specialization on methods, instruments, or additional counseling may apply under an extensive research attempt regarding contributing factors that boost the students' English language performance

\section{References}

[1] R. Lakoff, Language and Women's Place, New York: Harper and Row, 1975

[2] L. Milroy, S. Margrain, "Vernacular Language Loyalty and Social Network," Journal of Language in Society, vol. 9, pp. 43-70, 1980

[3] J. Cheshire, "The Relationship Between Language and Sex in English," Handbook of Dialects and Language Variation, Diego: Academic Press, 1998.

[4] L. Hirschman, "Female-Male Differences in Conversational Interaction," Journal of Language in Society, vol. 23, pp. 427-442, 1994 . 
[5] S. A. A. Ismail. "Exploring Students' Perceptions of ESL Writing," Journal of English Language Teaching, vol. 4, issue 19, pp. 73-83, 2011.

[6] H. Reeves, S. Baden, Gender and Development: Concepts and Definitions, Brighton: BRIDGE Institute of Development Studies University of Sussex, 2000.

[7] M. Holmes, What Is Gender? Sociological Approach, London: Sage, 2007.

[8] D. Haig, "The Inexorable Rise of Gender and the Decline of Sex: Social Change in Academic Titles," Archives of Sexual Behavior, vol. 33, issue 2, pp. 87-96, 2004.

[9] J. R. Udry, "The Nature of Gender," Journal of Demography, vol. 31, issue 4, pp. 561-573, 1994.

[10] R. Wardhaugh, An Introduction to Sociolinguistics, Oxford: Blackwell Publishing, 2006.

[11] A. Hancock, et. al, "Influence of Communication Partner's Gender on Language," Journal of Language and Social Psychology, vol. 10, pp. 1-19, 2014.

[12] A. Nemati, J. M. Bayer, "Gender Differences in the Use of Linguistic Forms in the Speech of Men Ana Women: A Comparative Study of Persian and English," Journal of Language in India, vol. 7, pp. 185-201, 2007

[13] J. Holmes, An Introduction to Sociolinguistics, London: Longman, 1992.

[14] P. Brown, How and Why Are Women More Polite: Some Evidence from A Mayan Community, Oxford: Blackwell, 1980

[15] K.Hyland, Teaching and Researching Writing, Harlow: Pearson, 2002.

[16] C. Gascoigne, "The Role of Gender in L2 Interaction: Socialization Via L2 Materials," Encuentro Revista de Investigación e Innovación en La Clase de Idi vol. 13, issue 14, pp. 81- 89, 2002.

[17] . S. Hedgcock, "Taking Stock of Research and Pedagogy in L2 Writing," Handbook of Research in Second Language Teaching and Learning, Mahwah, NJ: Lawrence Erlbaum Associates, 2005.

[18] E. Hinkel, Teaching Academic ESL Writing: Practical Techniques in Vocabulary and Grammar, Mahwah, NJ: Lawrence Erlbaum Associates, 2004.

[19] D. Ferris, J. S. Hedgcock, Teaching ESL Composition: Purpose, Process, and Practice, $2^{\text {nd }}$ ed. Mahwah, NJ: Lawrence Erlbaum Associates, 2005.

[20] P. Kelly, “How Do ESL Writers Compose?," Australian Review of Applied Linguistics, vol. 9, 1986.

[21] A. Cumming, "Writing Expertise and Second Language Proficiency," Journal of Language Learning, vol. $39,1989$.

[22] M. D. C. Arellano, "Gender Differences in Reading Comprehension Achievement in English As A Foreign Language in Compulsory Secondary Education", Journal of Physical and Social Sciences, pp. 67-84, 2012.

[23] L. Q. Trang, N. T. M. Hoa, "Student Writing Process, Perceptions, Problems, and Strategies in Writing Academic Essays in A Second Language: A Case Study", VNU Journal of Science, Foreign Language, vol. 24, pp. 184-197, 2008.

[24] F. Crosby, L. Nyquist. "The Female Register: An Empirical Study of Lakoff's Hypothesis", Journal of Language in Society, vol. 6, pp. 313-322, 1977.

[25] J. W. Creswell, Research Design: Qualitative, Quantitative and Mixed Methods Approaches, $4^{\text {th }}$ ed. California: Sage, 2013.

[26] G. B. Rossman, B. L. Wilson. "Numbers and Words: Combining Quantitative and Qualitative Methods in A Single Large-Scale Evaluation Study", Journal of Evaluation Review, vol. 9, issue 5, pp. 627-643, 1985.

[27] C. A. Mertler, "Practical Assessment, Research and Evaluation", Journal of Peer-Review Electronic, vol. 7, issue 25, pp. 1-8, 2001.

[28] B. S. Azzar, Understanding and Using English Grammar, $2^{\text {nd }}$ ed. New Jersey: Prentice Hall Regents, 1989.

[29] J. P. Guilford, Fundamental Statistics in Psychology and Education, New York: Mc Graw-Hill Book Co. Inc, 1956. 